\title{
Thermococcus piezophilus sp. nov., a novel hyperthermophilic and piezophilic archaeon with a broad pressure range for growth, isolated from a deepest hydrothermal vent at the Mid-Cayman Rise *
}

\author{
Dalmasso Cécile 1, 2, 3, Oger Philippe ${ }^{4}$, Selva Gwendoline 1, 2, 3, Courtine Damien 1, 2, 3 , \\ L'Haridon Stéphane $^{1,2,3}$, Garlaschelli Alexandre ${ }^{1,2,3}$, Roussel Erwan ${ }^{1,2,3}$, Miyazaki Junichi ${ }^{5}$, \\ Reveillaud Julie ${ }^{1,2,3}$, Jebbar Mohamed ${ }^{1,2,3}$, Takai Ken ${ }^{5}$, Maignien Lois ${ }^{1,2,3}$, Alain Karine ${ }^{1,2,3, \text {, }}$
}

${ }^{1}$ Université de Bretagne Occidentale (UBO, UEB), Institut Universitaire Européen de la Mer (IUEM) UMR 6197, Laboratoire de Microbiologie des Environnements Extrêmes (LM2E), Place Nicolas Copernic, F-29280 Plouzané, France

${ }^{2}$ CNRS, IUEM - UMR 6197, Laboratoire de Microbiologie des Environnements Extrêmes (LM2E), Place Nicolas Copernic, F-29280 Plouzané, France

${ }^{3}$ Ifremer, UMR 6197, Laboratoire de Microbiologie des Environnements Extrêmes (LM2E), Technopôle Pointe du diable, F-29280 Plouzané, France

${ }^{4}$ Université de Lyon, INSA Lyon, CNRS UMR 5240, 11 Avenue Jean Capelle, F-69621 Villeurbanne, France

${ }^{5}$ Department of Subsurface Geobiological Analysis and Research (D-SUGAR), Japan Agency for Marine-Earth Science and Technology (JAMSTEC), 2-15 Natsushima-cho, Yokosuka 237-0061, Japan

${ }^{*}$ Corresponding author : Karine Alain, email address : Karine.Alain@univ-brest.fr

* Note: The EMBL/GenBank/DDBJ 16S rRNA gene sequence accession number of strain CDGS ${ }^{\top}$ is LN 878294. Accession number of genome sequence of strain $\mathrm{CDGS}^{\top}$ is $\mathrm{CP} 015520$.

\begin{abstract}
:
A novel strictly anaerobic, hyperthermophilic archaeon, designated strain CDGS ${ }^{\prime}$, was isolated from a deep-sea hydrothermal vent in the Cayman Trough at $4964 \mathrm{~m}$ water depth. The novel isolate is obligate anaerobe and grows chemoorganoheterotrophically with stimulation of growth by sulphur containing compounds. Its growth is optimal at $75^{\circ} \mathrm{C}, \mathrm{pH} 6.0$ and under a pressure of $50 \mathrm{MPa}$. It possesses the broadest hydrostatic pressure range for growth that has ever been described for a microorganism. Its genomic DNA G + C content is $51.11 \mathrm{~mol} \%$. The novel isolate belongs to the genus Thermococcus. Phylogenetic analyses indicated that it is most closely related to Thermococcus barossii DSM $17882^{\top}$ based on its 16S rRNA gene sequence, and to 'Thermococcus onnurineus' NA1 based on its whole genome sequence. The average nucleotide identity scores with these strains are $77.66 \%$ for $T$. barossii and $84.84 \%$ for ' $T$. onnurineus', respectively.
\end{abstract}


Based on the draft whole genome sequence and phenotypic characteristics, strain CDGS $^{\top}$ is suggested to be separated into a novel species within the genus Thermococcus, with proposed name

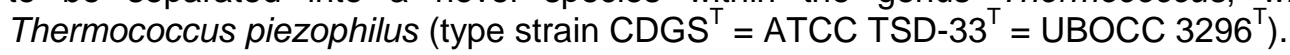

Keywords : Thermococcus, piezophile, hydrothermal vent, Cayman Trough

\section{Introduction}

Deep-sea hydrothermal vents are characterized by steep physical-chemical gradients between hot reduced streams (up to $450^{\circ} \mathrm{C}$ ) and cold $\left(2-4^{\circ} \mathrm{C}\right.$ ) with neutral $\mathrm{pH}$ surrounding seawater. These ecosystems are ideal to search for poly-extremophilic microorganisms with unique combination of extreme growth conditions. Since 1977 and the discovery of black smokers, numerous thermophilic and hyperthermophilic microorganisms have been isolated from deep-sea vents $[8,17]$. Among them, only four Bacteria and eleven Archaea are piezophiles or obligate piezophiles, e.g. requirering high hydrostatic pressure for growth [12]. 
Molecular inventories of the microbial diversity and culture-based approaches have repeatedly demonstrated that Thermococcales are common inhabitants of the hot area of the hydrothermal ecosystem [1]. The order Thermococcales encompasses three genera: Thermococcus [27], Pyrococcus [7] and Palaeococcus [23]. Representatives of the genus Thermococcus are all hyperthermophilic chemoorganoheterotrophs fermenting notably peptides and polysaccharides and reducing sulphur species. There are also two Thermococcus isolates able to grow lithotrophically by carboxydotrophy [22].

Currently, thirty two species of Thermococcus have been fully characterized with validly published names (source:

http://www.bacterio.net/). Only 15 genomes of Thermococcus are available in public databases. In this study, a novel Thermococcus isolate, referenced as strain CDGS $^{\mathrm{T}}$, was isolated from the deepest known deep-sea hydrothermal vent (the Beebe vent field, so-called Piccard). Its physiology and its genome were analyzed, and showed a wide physiological tolerance for the novel isolate to hydrostatic pressure as well as its taxonomic separation into a new species.

\section{Materials and Methods}

In June 2013, chimney fragments were collected by the DSV Shinkai 6500 from the Beebe vent field $\left(18^{\circ} 32.7881^{\prime} \mathrm{N}, 81^{\circ} 43.11844^{`} \mathrm{~W}\right)$ in the Cayman Trough, at a depth of 4964 $\mathrm{m}$, during an expedition (YK13-05) of the oceanographic cruise -QUELLE2013\| using RV Yokosuka. Chimney fragments were collected in small boxes and lifted up to the surface on the DSV. Once onboard, subsamples were immediately transferred anaerobically into sterile Schott vials, and stored at $4{ }^{\circ} \mathrm{C}$.

Samples were then transferred into anaerobic medium (DSM 141 modified medium) for enrichment cultures, under an atmosphere of $\mathrm{H}_{2} / \mathrm{CO}_{2}(80 / 20,2 \mathrm{~atm})$ and incubated at $60^{\circ} \mathrm{C}$, as described in Supplementary Material (SM). Isolation was performed by three repeated 
streaking on plates, at $70^{\circ} \mathrm{C}$, onto modified Ravot medium (see SM). After six days of incubation, a single white colony was picked and referenced as strain CDGS $^{\mathrm{T}}$.

Morphological characteristics of the cells were determined by light microscopy (BX60, Olympus) and scanning electron microscopy

(SEM) (Quanta 200, FEI).

The physiological characterization (substrate utilization, antibiotic resistance, etc.) of the novel isolate was carried out in triplicates in modified Ravot medium at $75^{\circ} \mathrm{C}$ unless otherwise noted, and is described in detail in SM. The temperature range for growth of the novel isolate was examined within a range of $55-95{ }^{\circ} \mathrm{C}$ with intervals of $2-5^{\circ} \mathrm{C}$. The $\mathrm{pH}$ range was checked within values 4.0-9.0. Salt tolerance was tested within range of $0-8 \%$ (w/v) $\mathrm{NaCl}$. The pressure range $(0.1,20,35,50,65,70,90,105,120,125,130$ and $135 \mathrm{MPa})$ was tested into highpressure high-temperature reactors. Growth yields and growth rates were measured, cellular activity was monitored (ATPmetry), morphology was visualized by SEM and sub-cultivations were done. Respiration and fermentation end products were identified by ionic chromatography.

The genomic DNA of the novel isolate was extracted with the kit Genomic-tip 20G and Genomic DNA buffer set (Qiagen $\left.{ }^{\circledR}\right)$ for wholegenome shotgun sequencing using the PacBio technology (one large insert library + two smartcells) (Duke University, Durham, USA). In addition, genomic DNA was purified with phenol-chloroform, and sequenced on a 318 Chip and the HiQ chemistry on an Ion Torrent PGM platform (IGFL, ENSL, Lyon, France) to correct and close-up the genome. The genome was assembled into one contig from the PacBio reads using the HGAP assembler included in a local installation of the PacBio SMRT portal (V. 2.3.0). The complete genome sequence was corrected by mapping assembly of the IonTorrent reads on the PacBio contig using MIRA 4 and the Newbler 2.8 suite of programs, and then manually curated. 
Annotation and comparative genomics were performed on the MicroScope Microbial Genome Annotation and Analysis Platform (MaGe) at the Genoscope [23,25]. Average nucleotide identity (ANI) scores were calculated using the JSpeciesWS [19], and the EzGenome program

(http://www.ezbiocloud.net/ezgenome/ani) with defaults parameters. In silico DNA-DNA hybridization $(\mathrm{DDH})$ estimations were calculated using the genome-to-genome distance calculator (GGDC2.0) [2,3]. Dot plot analyses of self-similarity between strain genomes were performed using the Nucmer V3.1 program, with default parameters.

16S rRNA gene sequence phylogenetic analyses were performed using Geneious version 6.1.6 (MUSCLE program for the alignment and manual refining). Phylogenetic reconstructions were made on the basis of evolutionary distance (neighbor-joining method with Jukes and Cantor corrections) [20] and maximum-likelihood (PHYML) [10], with 1000 bootstrap replications. Ribosomal protein sequence phylogenetic analyses were performed using PHYML. Ribosomal proteins were identified in complete genomes and aligned individually with MUSCLE. Alignments were optimized manually before concatenation. The phylogenetic reconstruction was done using PHYML excluding invariable sites from the analysis, using the LG model and a model-given amino acid equilibrium frequencies. The robustness of the inferred topology was assessed with 1000 bootstrap replications.

Pairwise 16S rRNA sequence similarity was calculated using the global alignment algorithm implemented at the EzTaxon-e server (http://eztaxon-e.ezbiocloud.net/) [13].

\section{Results \& discussion}

The ultraslow spreading Mid-Cayman Rise hosts the deepest known hydrothermal vent field, the Beebe vent field, at $5000 \mathrm{~m}$ water depth [9]. This active vent field is characterized 
by end-member fluids showing acidic $\mathrm{pH}$ (3.2), high temperature (close to $400^{\circ} \mathrm{C}$ ), low methane content, and high concentrations of hydrogen (>20 mM) and sulphide [18]. The novel isolate $\mathrm{CDGS}^{\mathrm{T}}$ was isolated from this site.

Cells of strain CDGS $^{\mathrm{T}}$ were motile irregular cocci of 0.8 to $1.7 \mu \mathrm{m}$ in diameter (average $1.1 \pm 0.3, n=18$ ) (Fig. S1). They produced membrane vesicles and connected to other cells with nanotubes.

At atmospheric pressure, the novel isolate grew at temperatures between 60 and $90{ }^{\circ} \mathrm{C}$ (Fig. 1) and with an optimal temperature of $75^{\circ} \mathrm{C}$. It was neutrophilic, growing from $\mathrm{pH} 5.5$ to 9.0, with a clear optimum at $\mathrm{pH} 6.0$ (Fig. 1). Its growth was optimal at the salinity of seawater (30 g/L NaCl), and within a range of $20-60 \mathrm{~g} / \mathrm{L} \mathrm{NaCl}$ (Fig. 1). Interestingly, the novel isolate was found to be piezophilic with an optimum pressure for growth at $50 \mathrm{MPa}$ (Table S1). Under optimal growth conditions $\left(75^{\circ} \mathrm{C}, \mathrm{pH} 6.0,30 \mathrm{~g} / \mathrm{L} \mathrm{NaCl}, 50 \mathrm{MPa}\right.$; with L-cystine), the doubling time of the novel isolate was 92 minutes.

The novel isolate was found to grow on complex organic substrates by fermentation without sulphur-containing compounds, but growth was stimulated by these sulphur species added to detoxify the excess of produced hydrogen. Growth was clearly stimulated by Lcystine, elemental sulphur (flower or colloidal) or polysulphur, that were all reduced to hydrogen sulphide. Best growth was observed on complex peptide carbon sources such as yeast extract, tryptone, peptone, beef extract and casamino acids in the presence of sulphur inorganic species. Slow growth was also observed on casein, $\mathrm{D}(+)$-galactose, $\mathrm{D}(+)$-glucose, $\mathrm{D}(+)$ mannose, xylan, succinate, glutamate and L-glycin in the presence of sulphur. Unlike $T$. onnurineus, we did not observe growth on formate as sole carbon and energy source, which is not surprising since the genome of strain $\mathrm{CDGS}^{\mathrm{T}}$ lacks a formate transporter. Growth by 
carboxydotrophy was not tested since $\mathrm{CooS}$ and $\mathrm{CooF}$, the two central proteins in the microbial carbon monoxide metabolism, are also absent from the genome sequence of strain CDGS $^{\mathrm{T}}$. The novel isolate was unable to reduce thiosulphate, sulphate, sulphite, nitrate and nitrite, and its growth was inhibited by oxygen. Metabolic end products are listed in Supplementary Material.

Strain CDGS $^{\mathrm{T}}$ was resistant to penicillin, kanamycin, chloramphenicol, streptomycin and vancomycin at $100 \mu \mathrm{g} / \mathrm{mL}$, and it was sensitive to simvastatin.

The final genome assembly comprised one circularized contig of 1,928,919 bp, with an average DNA G+C content of $51.11 \mathrm{~mol} \%$. As for other Thermococcales, there is one copy of the 16S-23S operon, two copies of 5S rRNAs and 45 tRNA genes. The genome could encode 2418 coding sequences (CDS) and 15 miscellaneous RNA. It had a protein coding density of $87.71 \%$. About $50 \%$ of all genes could be classified into Cluster of Orthologous Groups (COG) of functions. Among the identified CDS, 15\% shared no homology with any previously reported sequences and 37\% were homologs of previously reported genes of unknown function.

Levels of $16 \mathrm{~S}$ rRNA gene sequence similarity with the closest relatives Thermococcus barossii DSM9535 ${ }^{\mathrm{T}}$ and _Thermococcus onnurineus ${ }^{6}$ str. NA1 were $99.31 \%$ and $99.30 \%$, respectively (Fig. S4). To further elucidate the taxonomic position of strain $\mathrm{CDGS}^{\mathrm{T}}$, (i) a phylogeny was constructed to compare concatenated ribosomal protein sequences from all available genomic sequences of Thermococcus species (Fig. 2), (ii) in silico DNA-DNA hybridizations were performed and (iii) average nucleotide identity (ANI) scores were calculated. The ANI scores between strain $\mathrm{CDGS}^{\mathrm{T}}$ and $=T$. onnurineus' str. NA1 on one hand, and strain $\mathrm{CDGS}^{\mathrm{T}}$ and T. barossii $\mathrm{DSM} 9535^{\mathrm{T}}$ on the other hand, were, respectively $84.84 \%$ and $77.66 \%$ with EzGenome (and $84.73 \%$ and $76.75 \%$ with JSpeciesWS) (Fig. 2), which are below the 95-96\% cut-off value for species delineation by this approach [19]. The digital DNA- 
DNA hybridization values (identities / total length) between strain $\operatorname{CDGS}^{\mathrm{T}}$ and (i) ${ }_{=} T$. onnurineus' str. NA1 and (ii) T. barossii DSM9535 $5^{\mathrm{T}}$ were (i) $50.50 \%$ and (ii) $21.70 \%$ respectively, which are far below the threshold value (70\%) for prokaryotic species differentiation [26]. These whole-genome analyses indicated that strain $\mathrm{CDGS}^{\mathrm{T}}$ represents a novel species that is most closely related to _Thermococcus onnurineus' strain NA1 (Fig. 2). Dot plot analyses of the regional self-similarity of these two genomes showed that the synteny was highly conserved between the two species with only few inversions (Fig. S3).

In comparison with phylogenetically related species of the genus Thermococcus (Table 1), strain $\mathrm{CDGS}^{\mathrm{T}}$ was distinguishable from its closest relatives by its genomic DNA G+C content, its substrate preferences, its capacity to grow without sulphur species, its optimal temperature and $\mathrm{pH}$ for growth, and its piezophilic trait and wide pressure range for growth. $\mathrm{A}$ comparative genomic study of Thermococcus species showed that strain $\mathrm{CDGS}^{\mathrm{T}}$ shared only one fifth of its proteins with other type strains of Thermococcus species with publicly available genomes, and onehalf with its closest relative $=T$. onnurineus ${ }^{\star}$ NA1 (Fig. 2). The main differences in genetic content between these two strains were observed in COG categories related to amino acid transport and metabolism, carbohydrate transport and metabolism, signal transduction mechanisms and groups of general function prediction or unknown functions (Table S2, Fig. 2). Of note, while both $\mathrm{CDGS}^{\mathrm{T}}$ and Thermococcus onnurineus' NA1 possess all the proteins required for organotrophic growth on peptides, amino acids, or sugars, CDGS ‘s genome lacks some CDS necessary to grow by carboxydotrophy or formate oxidation.

In view of all above mentioned phylo-phenetic distinctive features, we propose that the isolate $\mathrm{CDGS}^{\mathrm{T}}$ should be assigned as the type strain of a novel species, for which the name Thermococcus piezophilus sp. nov. is proposed. 
As stated above, the novel isolate is piezophilic. Its optimal pressure for growth is 50 $\mathrm{MPa}$, the hydrostatic pressure of its natural habitat, as repeatedly examined using multiple proxies (lag phase duration, growth rate, growth yield) (Table S1). Strain CDGS $^{\mathrm{T}}$ grew well under pressures up to $105 \mathrm{MPa}$ at the optimal growth temperature of $75^{\circ} \mathrm{C}$ (Fig. 1, Fig. S2). Within 105-125 MPa, growth yield was very low but reproducible. Above $125 \mathrm{MPa}$, the growth yield was negligible. Intracellular ATP (iATP) content per cell at $120 \mathrm{MPa}$ was similar to the optimal $50 \mathrm{MPa}$ pressure (Table S3), that was consistent with observations of cell growth at this pressure. At 125 and $130 \mathrm{MPa}$, iATP was ca. 10 times higher indicating a higher activity of cell metabolism, and probably the activation of cell stress responses. After $38 \mathrm{~h}$ of incubation at $135 \mathrm{MPa}$, we observed only a fewer decrease in cell concentration, and iATP content was close to the detection limit, suggesting no biomass growth had occurred at $135 \mathrm{MPa}$ (Fig. S2, Table S3). No visible alterations of cell walls or morphological changes were observed. To further confirm growth, maintenance or survival under these extreme high-pressure conditions (125-135 MPa), we performed subcultures at atmospheric pressure. We were able to get growth for cells from all pressure conditions tested, confirming that strain $\mathrm{CDGS}^{\mathrm{T}}$ cells survived at least $38 \mathrm{~h}$ at $135 \mathrm{MPa}$. Interestingly, at atmospheric pressure, iATP content was higher than at the optimal pressure for growth (Table S3), which may reflect the activation of stress response mechanisms. The induction of the stress response under low hydrostatic pressure is a characteristic of piezophiles $[4,16]$.

These results show that strain $\mathrm{CDGS}^{\mathrm{T}}$ exhibits the broad pressure range for growth, whether among psychrophiles, mesophiles or hyperthermophiles [12], growing effectively from atmospheric pressure to at least $120 \mathrm{MPa}$, and with difficulty up to $130 \mathrm{MPa}$. These extreme pressures correspond to the pressure of a water column of 12 to $13 \mathrm{~km}$ depth, greater than the pressure measured at the bottom of the deepest parts of the ocean in the Mariana 
Trench. The archaea Pyrococcus yayanosii and Methanocococcus thermolithotrophicus hold the previous known record for a pressure range for growth of $100 \mathrm{MPa}$ [12]. In conclusion, Thermococcus piezophilus represents an excellent model of archaea to study microbial adaptation to hydrostatic pressure at high temperatures.

There are many piezophilic strains within the order Thermococcales [12]. This feature might be helpful for their oceanic dispersal over long distances, including in the abysses and in the hadal zones.

\section{Description of Thermococcus piezophilus sp. nov.}

Thermococcus piezophilus (pi.e.zo.phi'lus. Gr. v. piezo, to press; N.L. adj. philus -a -um (from Gr. adj. philos - $\hat{e}$-on), loving; N.L. masc. adj. piezophilus, loving pressure).

Cells are irregular motile cocci. Obligately anaerobic. Obligate chemoorganoheterotroph; Grows preferentially on complex peptide organics such as yeast extract, peptone, tryptone, casamino acids and beef extract. Poor growth on a few organic acids, mono- and polysaccharides. Elemental sulphur, L-cystine or polysulphur are not required but definitely stimulate growth.

Optimal growth occurs at $75^{\circ} \mathrm{C}, \mathrm{pH} 6.0$ and $3 \% \mathrm{NaCl}$. Piezophilic, growing optimally under $50 \mathrm{MPa}$. The doubling time is $92 \mathrm{~min}$ under optimal growth conditions.

The type strain, CDGS $^{\mathrm{T}}\left(=\mathrm{ATCC}\right.$ TSD- $33^{\mathrm{T}}=$ UBOCC $3296^{\mathrm{T}}$ ) was isolated from a chimney wall material of the $\sim 5 \mathrm{~km}$ water depth Beebe vent field, at the Mid-Cayman Rise.

The DNA G+C content of this strain is $51.11 \mathrm{~mol} \%$. 


\section{Acknowledgements}

We are grateful to the operation teams of DSV Shinkai 6500 and the crews of RV Yokosuka for sample collection, to Tiphaine Birien, Matthieu

Landreau, Myriam Georges and Yann Moalic for their constructive comments or punctual help, and to Odile Trambouze for her help with ATPmetry measurements.

The research leading to these results has received funding from the EU FP7 Project $M a C u M B A$ under grant agreement $\mathrm{n}^{\circ} 311975$. This work was also supported by the PICS-InEE Phypress, the PHC Cai Yuanpei Provirvent ( $\mathrm{N}^{\circ}$ 34634WE), the program MERLIN Abyss, the "Laboratoire d'Excellence" LabexMER (ANR-10-LABX-19) and the program "Investissements d'Avenir".

\section{References}

[1] Anderson, R.E., Sogin, M.L., Baross, J.A. (2015) Biogeography and ecology of the rare and abundant microbial lineages in deep-sea hydrothermal vents. FEMS Microbiol. Ecol. 91(1), 1-11, Doi: 10.1093/femsec/fiu016.

[2] Auch, A.F., von Jan, M., Klenk, H.-P., Göker, M. (2010) Digital DNA-DNA hybridization for microbial species delineation by means of genome-to-genome sequence comparison. Stand. Genomic Sci. 2(1), 117-34, Doi: 10.4056/sigs.531120.

[3] Auch, A.F., Klenk, H.-P., Göker, M. (2010) Standard operating procedure for calculating genome-to-genome distances based on highscoring segment pairs. Stand. Genomic Sci. 2(1), 142-8, Doi: 10.4056/sigs.541628.

[4] Cario, A., Jebbar, M., Thiel, A., Kervarec, N., Oger, P.M. (2016) Molecular chaperone accumulation as a function of stress evidences adaptation to high hydrostatic pressure in the piezophilic archaeon Thermococcus barophilus. Sci. Rep. 6, 29483, Doi:10.1038/srep29483.

[5] Cord-Ruwisch, R. (1985) A quick method for the determination of dissolved and precipitated sulfides in cultures of sulfate-reducing bacteria. J. Microbiol. Methods 4(1), 33-6, Doi: 10.1016/0167-7012(85)90005-3.

[6] Duffaud, G.D., d'Hennezel, O.B., Peek, A.S., Reysenbach, A.L., Kelly, R.M. (1998) Isolation and characterization of Thermococcus barossii, sp. nov., a hyperthermophilic archaeon isolated from a hydrothermal vent flange formation. Syst. Appl. Microbiol. 21(1), 40-9, Doi: 10.1016/S0723-2020(98)80007-6. 
[7] Fiala, G., Stetter, K.O. (1986) Pyrococcus furiosus sp. nov. represents a novel genus of marine heterotrophic archaebacteria growing optimally at $100^{\circ} \mathrm{C}$. Arch. Microbiol. 145(1), 56-61, Doi: 10.1007/BF00413027.

[8] Flores, G.E., Reysenbach, A.-L. (2011) Hydrothermal Environments, Marine. In: Reitner, J., Thiel, V., (Eds.), Encyclopedia of Geobiology, Springer Netherlands, pp. 456-67.

[9] German, C.R., Bowen, A., Coleman, M.L., Honig, D.L., Huber, J.A., Jakuba, M.V., Kinsey, J.C., Kurz, M.D., Leroy, S., McDermott, J.M., others (2010) Diverse styles of submarine venting on the ultraslow spreading Mid-Cayman Rise. Proc. Natl. Acad. Sci. 107(32), 14020-5.

[10] Guindon, S., Dufayard, J.-F., Lefort, V., Anisimova, M., Hordijk, W., Gascuel, O. (2010) New algorithms and methods to estimate maximum-likelihood phylogenies: assessing the performance of PhyML 3.0. Syst. Biol. 59(3), 307-21, Doi: 10.1093/sysbio/syq010.

[11] Ikeda, S., Satake, H., Hisano, T., Terazawa, T. (1972) Potentiometric argentimetric method for the successive titration of sulphide and dissolved sulphur in polysulphide solutions. Talanta 19(12), 1650-4, Doi: 10.1016/0039-9140(72)80240-6.

[12] Jebbar, M., Franzetti, B., Girard, E., Oger, P. (2015) Microbial diversity and adaptation to high hydrostatic pressure in deep-sea hydrothermal vents prokaryotes. Extremophiles 19(4), 721-40, Doi: 10.1007/s00792-015-0760-3.

[13] Kim, O.-S., Cho, Y.-J., Lee, K., Yoon, S.-H., Kim, M., Na, H., Park, S.-C., Jeon, Y.S., Lee, J.-H., Yi, H., Won, S., Chun, J. (2012) Introducing EzTaxon-e: a prokaryotic 16S rRNA gene sequence database with phylotypes that represent uncultured species. Int. J. Syst. Evol. Microbiol. 62(Pt 3), 716-21, Doi: 10.1099/ijs.0.038075-0.

[14] Kobayashi, T., Kwak, Y.S., Akiba, T., Kudo, T., Horikoshi, K. (1994) Thermococcus profundus sp. nov., a new hyperthermophilic archaeon isolated from a deep-sea hydrothermal vent. Syst. Appl. Microbiol. 17(2), 232-6.

[15] Kuwabara, T., Minaba, M., Iwayama, Y., Inouye, I., Nakashima, M., Marumo, K., Maruyama, A., Sugai, A., Itoh, T., Ishibashi, J., Urabe, T., Kamekura, M. (2005) Thermococcus coalescens sp. nov., a cell-fusing hyperthermophilic archaeon from Suiyo Seamount. Int. J. Syst. Evol. Microbiol. 55(6), 2507-14, Doi: 10.1099/ijs.0.63432-0.

[16] Marteinsson, V.T., Reysenbach, A.L., Birrien, J.L., Prieur, D. (1999) A stress protein is induced in the deep-sea barophilic hyperthermophile Thermococcus barophilus when grown under atmospheric pressure. Extremophiles 3, 277-282.

[17] Orcutt, B.N., Sylvan, J.B., Knab, N.J., Edwards, K.J. (2011) Microbial ecology of the dark ocean above, at, and below the seafloor. Microbiol. Mol. Biol. Rev. 75(2), 361-422, Doi: 10.1128/MMBR.00039-10.

[18] Reveillaud, J., Reddington, E., McDermott, J., Algar, C., Meyer, J.L., Sylva, S., Seewald, J., German, C.R., Huber, J.A. (2016) Subseafloor microbial communities in hydrogenrich vent fluids from hydrothermal systems along the Mid-Cayman Rise. Environ. Microbiol., 18(6),1970-1987, Doi: 10.1111/1462-2920.13173.

[19] Richter, M., Rosselló-Móra, R., Glöckner, F.O., Peplies, J. (2015) JSpeciesWS: a web server for prokaryotic species circumscription based on pairwise genome comparison. Bioinformatics, btv681, Doi: 10.1093/bioinformatics/btv681.

[20] Saitou, N., Nei, M. (1987) The neighbor-joining method: a new method for reconstructing phylogenetic trees. Mol. Biol. Evol. 4(4), 406- 25.

[21] Seob, B.S., Kim, Y.J., Yang, S.H., Lim, J.K., Jeon, J.H., Lee, H.S., Kang, S.G., Kim, S.J., Lee, J.-H. (2006) Thermococcus onnurineus sp. 
nov., a hyperthermophilic archaeon isolated from a deep-sea hydrothermal vent area at the PACMANUS field. J. Microbiol. Biotechnol. 16(11), 1826-31.

[22] Sokolova, T.G., Henstra, A.-M., Sipma, J., Parshina, S.N., Stams, A.J.M., Lebedinsky, A.V. (2009) Diversity and ecophysiological features of thermophilic carboxydotrophic anaerobes: Thermophilic carboxydotrophic anaerobes. FEMS Microbiol. Ecol. 68(2), 131-41, Doi: 10.1111/j.1574-6941.2009.00663.x.

[23] Takai, K., Sugai, A., Itoh, T., Horikoshi, K. (2000) Palaeococcus ferrophilus gen. nov., sp. nov., a barophilic, hyperthermophilic archaeon from a deep-sea hydrothermal vent chimney. Int. J. Syst. Evol. Microbiol. 50(2), 489-500.

[24] Vallenet, D., Belda, E., Calteau, A., Cruveiller, S., Engelen, S., Lajus, A., Le Fèvre, F., Longin, C., Mornico, D., Roche, D., Rouy, Z., Salvignol, G., Scarpelli, C., Thil Smith, A.A., Weiman, M., Médigue, C. (2013) MicroScope—an integrated microbial resource for the curation and comparative analysis of genomic and metabolic data. Nucleic Acids Res. 41(Database issue), D636-47, Doi:

10.1093/nar/gks1194.

[25] Vallenet, D., Engelen, S., Mornico, D., Cruveiller, S., Fleury, L., Lajus, A., Rouy, Z., Roche, D., Salvignol, G., Scarpelli, C., Médigue, C. (2009) MicroScope: a platform for microbial genome annotation and comparative genomics. Database J. Biol. Databases Curation 2009, Doi: 10.1093/database/bap021.

[26] Wayne, L.G., Brenner, D.J., Colwell, R.R., Grimont, P.A.D., Kandler, O., Krichevsky, M.I., Moore, L.H., Moore, W.E.C., Murray, Rge., Stackebrandt, E., others (1987) Report of the ad hoc committee on reconciliation of approaches to bacterial systematics. Int. J. Syst. Evol. Microbiol. 37(4), 463-4.

[27] Zillig, W., Holz, I., Janekovic, D., Schäfer, W., Reiter, W.D. (1983) The archaebacterium Thermococcus celer represents, a novel genus within the thermophilic branch of the archaebacteria. Syst. Appl. Microbiol. 4(1), 88-94, Doi: 10.1016/S0723-2020(83)80036- 
Table 1. Characteristics differentiating strain $\mathrm{CDGS}^{\mathrm{T}}$ from closest species of the genus Thermococcus.

1, Strain CDGS ${ }^{\mathrm{T}}$ (this study); 2, 'T. onnurineus' [21] ; 3, T. barossii [6]; 4, T. profundus [14]; 5, T. coalescens [15]. Legend: S, stimulatory ; R, required ; $\S$, information deduced from the genome sequence ; ND, not determined.

\begin{tabular}{|c|c|c|c|c|c|}
\hline Characteristic & 1 & 2 & 3 & 4 & 5 \\
\hline Geographical origin & $\begin{array}{c}\text { Beebe Vent Field, Mid-Cayman } \\
\text { Rise }\end{array}$ & $\begin{array}{c}\text { Manus basin, Papua New } \\
\text { Guinea }\end{array}$ & Juan de Fuca Ridge & $\begin{array}{l}\text { Middle Okinawa } \\
\text { Trough }\end{array}$ & $\begin{array}{l}\text { Suiyo Seamount, Izu- } \\
\text { Bonin Arc }\end{array}$ \\
\hline Sample Type & Hydrothermal chimney rock & $\begin{array}{l}\text { Hydrothermal chimney } \\
\text { rock }\end{array}$ & Hydrothermal chimney rock & Hydrothermal vent & Hydrothermal fluids \\
\hline Depth (m) & 4969 & 1650 & ND & 1395 & 1380 \\
\hline Size $(\mu \mathrm{m})$ & $0.8-2.0$ & $0.5-1.0$ & $0.7-3.7$ & $1.0-2.0$ & $0.7-3.7$ \\
\hline Motility & + & + & - & + & + \\
\hline $\begin{array}{l}\text { Temperature } \\
\left({ }^{\circ} \mathrm{C} ; \text { Optimum }\right)\end{array}$ & $60-95^{\circ} \mathrm{C}\left(75^{\circ} \mathrm{C}\right)$ & $63-90{ }^{\circ} \mathrm{C}\left(80^{\circ} \mathrm{C}\right)$ & $60-92{ }^{\circ} \mathrm{C}\left(82.5^{\circ} \mathrm{C}\right)$ & $50-90{ }^{\circ} \mathrm{C}\left(80{ }^{\circ} \mathrm{C}\right)$ & $57-90{ }^{\circ} \mathrm{C}\left(87^{\circ} \mathrm{C}\right)$ \\
\hline pH (Optimum) & $5.5-9.0(\mathrm{pH} 6.0)$ & 5.0-9.0 (pH 8.5) & $4.0-9.0(\mathrm{pH} 6.5-7.5)$ & 4.5-8.5 (Opt. ND) & $5.2-8.7(\mathrm{pH} 6.5)$ \\
\hline $\mathrm{NaCl}$ (optimum) (\%) & $2.0-6.0(3.0)$ & $1.0-5.0(3.5)$ & ND & $1.0-6.0$ (Opt. ND) & $1.5-4.5(2.5)$ \\
\hline Doubling time (min) & 92 & 92 & 35 & 50 & 150 \\
\hline Sulphur requirement & $\mathrm{S}$ & $\mathrm{R}$ & $\mathrm{R}$ & $\mathrm{R}$ & S \\
\hline \multicolumn{6}{|l|}{ Growth on: } \\
\hline Pyruvate & - & - & - & + & - \\
\hline Maltose & - & - & + & + & - \\
\hline Starch & - & + & ND & + & - \\
\hline Yeast Extract & + & + & + & + & + \\
\hline Peptone & + & + & + & + & ND \\
\hline $\mathrm{CO}$ & $-\S$ & + & ND & ND & ND \\
\hline $\begin{array}{c}\text { DNA G+C content } \\
(\mathrm{mol} \%)\end{array}$ & 51.1 & 52 & 54.7 & 50 & 53.9 \\
\hline
\end{tabular}


Fig. 1. Growth rates of strain $\mathrm{CDGS}^{\mathrm{T}}$ at different salinities (A), temperatures (B) and pHs (C). Growth yields of the novel isolate after $38 \mathrm{~h}$ incubations at different pressures (D).
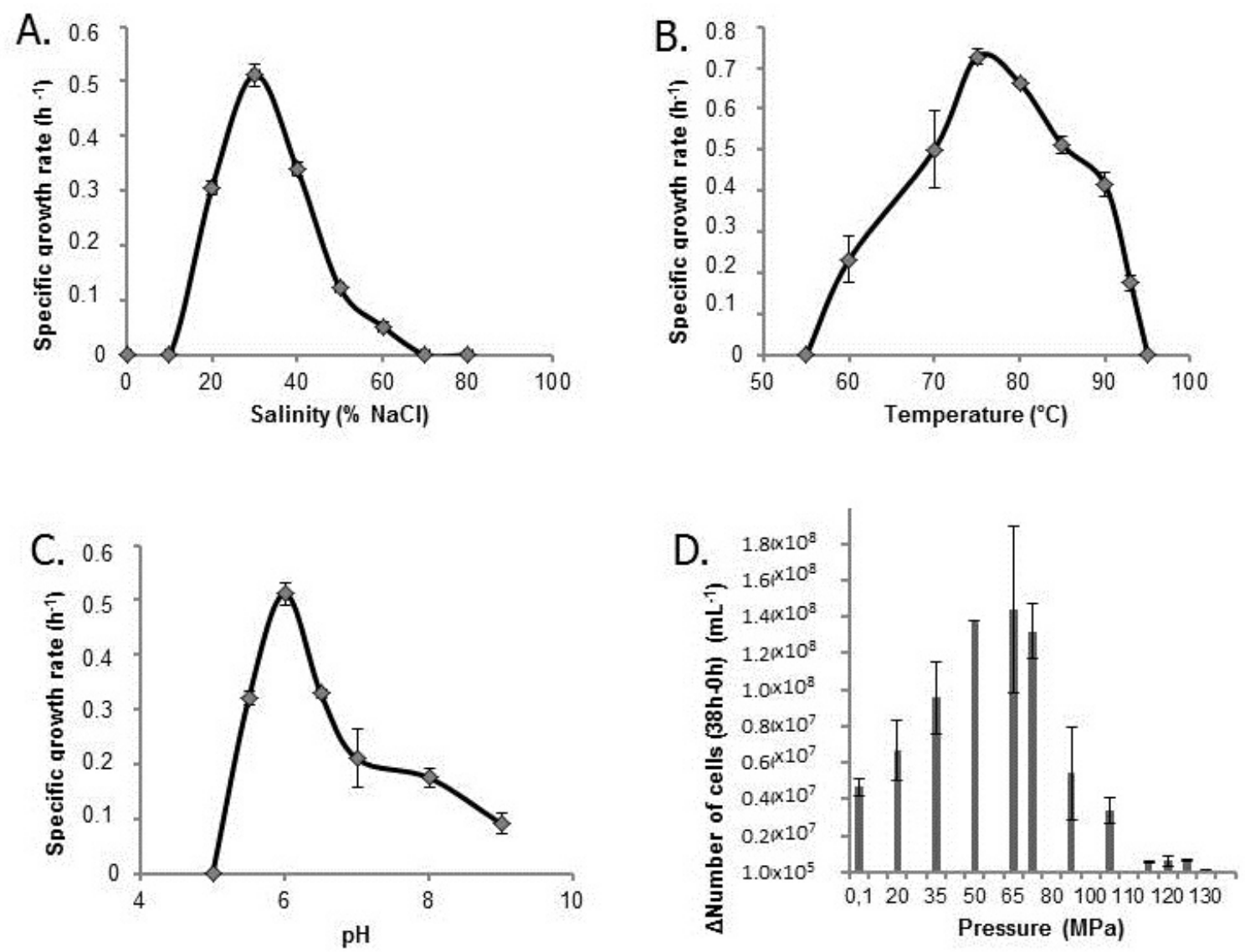

Fig. 2. Left side: Phylogenetic relationships of strain $\mathrm{CDGS}^{\mathrm{T}}$ and other Thermococcus species based on ribosomal protein sequences. The topology shown was calculated with PHYML. Accession numbers are given in brackets. Bootstrap values (\%) are based on 1000 replicates. Bar, 2 substitutions per 100 nt. Right side. Venn diagram of orthologous genes showing the pan/core genomes of strain $\mathrm{CDGS}^{\mathrm{T}}$, ' $T$. onnurineus' str. NA1 and the five type species of the Thermococcus genus with publicly available genomes $(T$. barophilus $\mathrm{MP}^{\mathrm{T}}$, T. gammatolerans $\mathrm{EJ}^{\mathrm{T}}$, T. kodakarensis $\mathrm{KOD} 1^{\mathrm{T}}$, T. sibiricus $\mathrm{MM} 379^{\mathrm{T}}$ and T. litoralis Ns- $\mathrm{C}^{\mathrm{T}}$ ). The Venn diagram is based on a threshold of $80 \%$ amino acid identity and $80 \%$ amino acid alignment coverage. Numbers shown in the Venn diagram correspond to the orthologous gene groups given in the respective patterns. Histograms 
show the distribution of COG groups within the strain-specific portions of the genomes. COG categories: A, RNA modification and processing; B, Chromatin structure and dynamics; C, Energy production and conversion; D, Cell cycle control, cell division, chromosome partitioning; E, Amino acid transport and metabolism; F, Nucleotide transport and metabolism; G, Carbohydrate transport and metabolism; H, Coenzyme transport and metabolism; I, Lipid transport and metabolism; J, Translation, ribosomal structure and biogenesis; K, Transcription; L, Replication, recombination and repair; M, Cell wall/membrane/envelope biogenesis; N, Cell motility; O, Post-translational modification, protein turnover, chaperones; P, Inorganic ion transport and metabolism; Q, Secondary metabolites biosynthesis, transport and catabolism; R, General function prediction only; S, Function unknown; T, Signal transduction mechanisms; U, Intracellular trafficking, secretion and vesicular transport; V, Defense mechanisms; W, Extracellular structures; Z, Cytoskeleton. Middle: Average Nucleotide Identity scores between the genomes of the novel strain and its two closest relatives calculated with EzGenome (§) and JSpeciesWS (¥) programs.

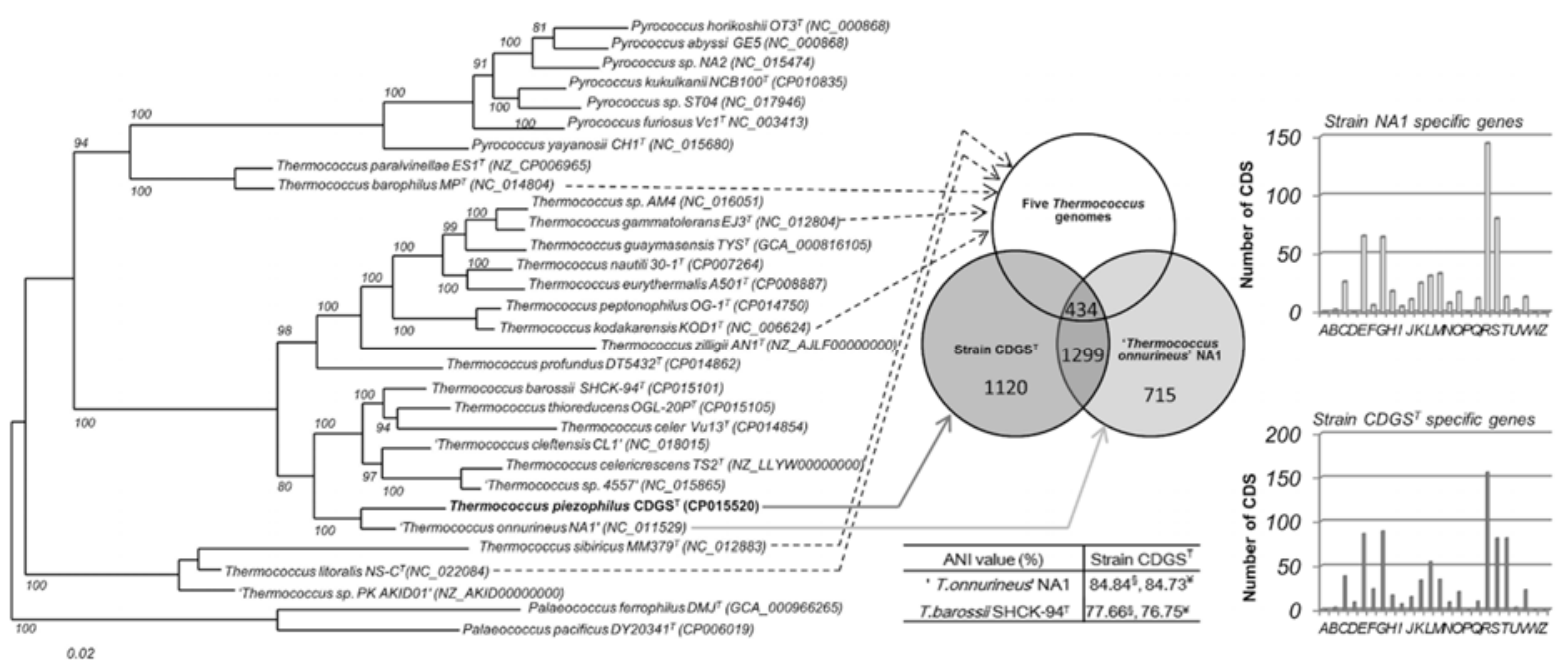




\section{Supplementary Information}

\section{Materials and Methods}

Enrichment and isolation

Chimney samples were incubated anaerobically for enrichment cultures in DSM 141 modified medium (per litre of distilled water: $18 \mathrm{~g} \mathrm{NaCl}, 4 \mathrm{~g} \mathrm{MgCl}_{2} \cdot 6 \mathrm{H}_{2} \mathrm{O}, 3.45 \mathrm{~g}$ $\mathrm{MgSO}_{4} \cdot 6 \mathrm{H}_{2} \mathrm{O}, 2 \mathrm{~g}$ yeast extract, $1.95 \mathrm{~g} \mathrm{MES} \mathrm{buffer,} 0.34 \mathrm{~g} \mathrm{KCl}, 0.25 \mathrm{~g} \mathrm{NH}_{4} \mathrm{Cl}, 0.14 \mathrm{~g}$ $\mathrm{CaCl}_{2} \cdot 2 \mathrm{H}_{2} \mathrm{O}, 0.002 \mathrm{~g} \mathrm{Fe}\left(\mathrm{NH}_{4}\right)_{2}\left(\mathrm{SO}_{4}\right)_{2} \cdot 6 \mathrm{H}_{2} \mathrm{O}, 0.001 \mathrm{~g}$ resazurin) with a $\mathrm{pH}$ adjusted to 6.5 . Medium was boiled for 3-5 minutes, cooled under flow of high purity nitrogen gas, then reduced with $0.5 \mathrm{~g}$ cysteine hydrochloride, and autoclaved (for $60 \mathrm{~min} 1 \mathrm{~atm}$ and $121^{\circ} \mathrm{C}$ ). Sterile solutions of vitamins and trace elements were added $10 \mathrm{~mL}$ each (see recipe of DSM medium 141, below). Initial enrichment cultures were incubated in vials reduced with $0.5 \mathrm{~g} \mathrm{~L}^{-}$

${ }^{1}$ sodium sulphide $\left(\mathrm{Na}_{2} \mathrm{~S} .9 \mathrm{H}_{2} \mathrm{O}\right)$ and incubated at $60^{\circ} \mathrm{C}$ under an atmosphere of $\mathrm{H}_{2} / \mathrm{CO}_{2}$ (80/20, 0.2 MPa). After two days of incubation, low cellular abundances were obtained in the enrichment cultures, suggesting that we did not enrich autotrophs but rather heterotrophs. The medium was then changed to stimulate heterotrophic growth. Subcultures and isolation were done in Ravot modified medium prepared without maltose, with a $\mathrm{pH}$ adjusted to 6.0 (per litre of distilled water: $30 \mathrm{~g} \mathrm{NaCl}, 3.3 \mathrm{~g}$ PIPES buffer, $2 \mathrm{~g}$ tryptone, $2 \mathrm{~g}$ yeast extract, $0.83 \mathrm{~g}$ sodium acetate trihydrate, $0.5 \mathrm{~g} \mathrm{KCl}, 0.5 \mathrm{~g} \mathrm{MgCl}_{2} \cdot 6 \mathrm{H}_{2} \mathrm{O}, 0.3 \mathrm{~g} \mathrm{NH}_{4} \mathrm{Cl}, 0.1 \mathrm{~g} \mathrm{CaCl}_{2} \cdot 2 \mathrm{H}_{2} \mathrm{O}$, $0.001 \mathrm{~g}$ resazurin). Medium was autoclaved and supplemented with $0.26 \mathrm{mM} \mathrm{KH}_{2} \mathrm{PO}_{4}, 0.20$ $\mathrm{mM} \mathrm{K}_{2} \mathrm{HPO}_{4}$ and $1 \mathrm{~mL}$ vitamin mixture (described in DSM medium 141). After degassing, medium was aliquoted anaerobically in vials, supplemented with $12 \mathrm{~g} / \mathrm{L}$ L-cystine, and reduced with $0.5 \mathrm{~g} / \mathrm{L}$ sodium sulphide $\left(\mathrm{Na}_{2} \mathrm{~S} \cdot 9 \mathrm{H}_{2} \mathrm{O}\right)$ just before inoculation. After two days of incubation, motile cocci were observed and subcultured under the same conditions. They were subsequently purified by three repeated streaking on plates, on the same medium solidified 
with gellan gum (Phytagel ${ }^{\mathrm{TM}}$, Sigma-Aldrich). Plates were incubated into anaerobic jars at 70 ${ }^{\circ} \mathrm{C}$ for six days. After the third transfer on plate, a single circular white colony was picked and referenced as strain $\mathrm{CDGS}^{\mathrm{T}}$. Purity of this isolate was confirmed by microscopy and sequencing of the 16S rRNA gene using five different primers.

\begin{tabular}{|c|c|c|c|}
\hline \multicolumn{4}{|c|}{ DSM medium 141, with modifications } \\
\hline \multicolumn{2}{|c|}{ Modified mineral basis } & & \\
\hline For $1 \mathrm{~L}$ & $\mathrm{~g}$ & & \\
\hline $\mathrm{KCl}$ & 0.34 & & \\
\hline $\mathrm{MgCl}_{2} \cdot 6 \mathrm{H}_{2} \mathrm{O}$ & 4.00 & \multirow{9}{*}{\multicolumn{2}{|c|}{$\begin{array}{l}\text { Dissolve the ingredients and then adjust the } \mathrm{pH} \text { to } \\
6.0 \text {. } \\
\text { Boil the medium for } 3-5 \text { minutes, and cool it under } \\
\text { a flow of high purity nitrogen gas. } \\
\text { Add } 0.5 \mathrm{~g} \text { cysteine hydrochloride. } \\
\text { Autoclave for } 60 \text { min at } 121^{\circ} \mathrm{C}, 1 \text { atm. } \\
\text { After autoclaving, flush the medium with a mixture } \\
\text { of high purity nitrogen gas. } \\
\text { Sterile solutions of vitamins and trace elements } \\
\text { (see below) are added } 10 \mathrm{~mL} \text { each to the cold } \\
\text { mineral basis. }\end{array}$}} \\
\hline $\mathrm{MgSO}_{4}-6 \mathrm{H}_{2} \mathrm{O}$ & 3.45 & & \\
\hline & \multirow{2}{*}{0.25} & & \\
\hline $\mathrm{NH}_{4} \mathrm{Cl}$ & & & \\
\hline $\mathrm{CaCl}_{2} \cdot 2 \mathrm{H}_{2} \mathrm{O}$ & 0.14 & & \\
\hline $\mathrm{K}_{2} \mathrm{HPO}_{4}$ & 0.14 & & \\
\hline $\mathrm{NaCl}$ & 18.00 & & \\
\hline $\mathrm{Fe}\left(\mathrm{NH}_{4}\right)_{2}\left(\mathrm{SO}_{4}\right)_{2} \cdot 6 \mathrm{H}_{2} \mathrm{O}$ & $2.00^{*}$ & & \\
\hline MES buffer & 1.95 & & \\
\hline Resazurin & 1 drop & & \\
\hline Distilled water & $1 \mathrm{~L}$ & & \\
\hline \multicolumn{4}{|c|}{$\begin{array}{l}\text { Medium is then aliquoted a naerobically into sterile vials. Gas phase is then replaced by a high purity } \mathrm{H}_{2} / \mathrm{CO}_{2} \\
\left(80 / 20,2 \mathrm{~atm}, 2 / 3^{\text {td }} \text { of gas phase in the vial) gas mixture. }\right.\end{array}$} \\
\hline \multicolumn{2}{|c|}{ Vitamin solution } & \multicolumn{2}{|c|}{ Trace element solution } \\
\hline For $1 \mathrm{~L}$ & $\mathrm{mg}$ & For $1 \mathrm{~L}$ & $\mathrm{~g}$ \\
\hline Biotin & 2.00 & Nitriloacetic acid & 1.50 \\
\hline Folic acid & 2.00 & $\mathrm{MgSO}_{4} \cdot 7 \mathrm{H}_{2} \mathrm{O}$ & 3.00 \\
\hline Pyridoxine- $\mathrm{HCl}$ & 10.00 & $\mathrm{MnSO}_{4} \cdot \mathrm{H}_{2} \mathrm{O}$ & 0.50 \\
\hline Thiamine- $\mathrm{HCl} \cdot 2 \mathrm{H}_{2} \mathrm{O}$ & 5.00 & $\mathrm{NaCl}$ & 1.00 \\
\hline Riboflavin & 5.00 & $\mathrm{FeSO} \mathrm{O}_{4} \cdot 7 \mathrm{H}_{2} \mathrm{O}$ & 0.10 \\
\hline Nicotinic acid & 5.00 & $\mathrm{COSO}_{4} 7 \mathrm{H}_{2} \mathrm{O}$ & 0.18 \\
\hline D-Ca-pantothenate & 5.00 & $\mathrm{CaCl}_{2} \cdot 2 \mathrm{H}_{2} \mathrm{O}$ & 0.10 \\
\hline B12 vitamin (cobalamin) & 0.10 & $\mathrm{ZnSO}_{4} 7 \mathrm{H}_{2} \mathrm{O}$ & 0.18 \\
\hline$\rho$-amino-benzoic acid & 5.00 & $\mathrm{CuSO}_{4} 5 \mathrm{H}_{2} \mathrm{O}$ & 0.01 \\
\hline Lipoic aciod & 5.00 & $\mathrm{KAl}\left(\mathrm{SO}_{4}\right)_{2} \cdot 12 \mathrm{H}_{2} \mathrm{O}$ & 0.02 \\
\hline Distilled water & 11 & $\mathrm{H}_{3} \mathrm{BO}_{3}$ & 0.01 \\
\hline \multirow{5}{*}{\multicolumn{2}{|c|}{ Sterilize by filtration (pores: $0.2 \mu \mathrm{m}$ ). }} & $\mathrm{Na}_{2} \mathrm{MoO}_{4} \cdot 2 \mathrm{H}_{2} \mathrm{O}$ & 0.01 \\
\hline & & $\mathrm{NiCl}_{2}-6 \mathrm{H}_{2} \mathrm{O}$ & 0.03 \\
\hline & & $\mathrm{Na}_{2} \mathrm{SeO}_{3}$ & $0.2^{*}$ \\
\hline & & Distilled water & $1 \mathrm{~L}$ \\
\hline & & \multicolumn{2}{|c|}{$\begin{array}{l}\text { Dissolve first the nitriloacetic acid, adjust the } \mathrm{pH} \text { to } \\
6.5 \text { and then add the other components. The final } \\
\mathrm{pH} \text { is adjusted to } 7.0 \text {. } \\
\text { Autoclave at } 121^{\circ} \mathrm{C} \text { and } 1 \mathrm{~atm} \text {, for } 1 \mathrm{~h} \text {. }\end{array}$} \\
\hline
\end{tabular}




\section{Physiological analyses}

Unless stated otherwise, the experiments were carried out anaerobically in triplicate in the presence of L-cystine and incubation was carried out in the dark, at $70{ }^{\circ} \mathrm{C}, \mathrm{pH} 6.0$ and with $30 \mathrm{~g} / \mathrm{L} \mathrm{NaCl}$. Growth was monitored either by flow cytometry enumeration (CyFlow Space, Partec) or by direct cell counting onto a modified Thoma chamber (depth $10 \mu \mathrm{m})$. In parallel, the production of hydrogen sulphide was measured by a colorimetric method [5]. Growth rates were calculated using linear regression analysis of 4 to 6 points along the linear portions of the growth curves.

The $\mathrm{pH}$ range for growth of the novel isolate was determined in Ravot modified medium prepared with various buffers (each at $20 \mathrm{mM}$, Sigma-Aldrich): for $\mathrm{pH} 4.0$ and 5.0, HOMOPIPES buffer; for $\mathrm{pH}$ 5.5-6.5, MES buffer; for $\mathrm{pH}$ 7.0, PIPES buffer; for $\mathrm{pH}$ 7.5-8.0, HEPES buffer; for $\mathrm{pH}$ 8.5, TAPS buffer; for $\mathrm{pH}$ 9.0, CAPSO buffer.

The pressure range for growth of the strain was tested in $5 \mathrm{~mL}$ syringes placed either into a high-pressure/high-temperature incubation system custom-built by Top-Industrie (Dammarie-les-Lys, France) or into home-made high pressure reactors (Oger laboratory, INSA Lyon). At the optimal temperature for growth $\left(75^{\circ} \mathrm{C}\right)$, growth yield after $14,18,24$ and 38 hours of incubation was monitored at the following hydrostatic pressures: $0.1,20,35,50$, $65,70,90,105,120,125,130$ and $135 \mathrm{MPa}$. Cell counts were done by flow cytometry and the level of cellular activity was monitored by ATPmetry using the ATPmetry HS kit $\left(\right.$ Biothema $\left.^{\circledR}\right)$ and the luminester C-110 $\left(\operatorname{Kikkoman}^{\circledR}\right)$. At the end of the incubations performed at the highest pressure conditions $(120,125,130$ and $135 \mathrm{MPa})$, the presence of viable cells was established by cultivation at atmospheric pressure $\left(75^{\circ} \mathrm{C}\right)$. Cell aspect was observed by SEM imaging. Growth rates around the optimal pressure $(40,50,60 \mathrm{MPa})$ were derived from a set of experiments performed with sampling at 2 to 3 hours intervals. 
The following carbon sources were tested, in triplicate, at $75^{\circ} \mathrm{C}$, in Ravot mineral medium supplemented with one of the following compound at a final concentration of 20 mM: $\mathrm{D}(-)$-fructose, $\mathrm{D}(+)$-galactose, $\mathrm{D}(+)$-glucose, $\mathrm{D}(+)$-mannose, $\mathrm{D}(-)$-ribose, $\mathrm{D}(+)$-xylose, dextrose $(\mathrm{D}(+)$-glucose, corn sugar), $\mathrm{D}(+)$-maltose, starch, xylan, methanol $(5 \mathrm{mM})$, fumarate, succinate, pyruvate, acetate, formate, $L$-cystein, $L$-glutamic acid, glycine, $L$-lysin, $L$ methionin, $L$-serine, $L$-valine, peptone, tryptone, yeast extract, beef extract, casamino acids and casein (casein acid hydrolysate, vitamins free). This experiment was performed, on the one hand, with these substrates tested as sole carbon sources and, on the other hand, with 0.05 $\%(\mathrm{w} / \mathrm{v})$ yeast extract for culture initiation. Unsupplemented medium was used as a negative control.

The ability of strain $\mathrm{CDGS}^{\mathrm{T}}$ to use electron acceptors was tested by adding elemental sulphur (12 g/L), L-cystine (12 g/L), sodium thiosulphate $(20 \mathrm{mM})$, sodium sulphate (20 $\mathrm{mM})$, sodium sulphite $(5 \mathrm{mM})$, polysulphur $(0.5 \mathrm{mM})$ [11], sodium nitrate $(20 \mathrm{mM})$, sodium nitrite $(5 \mathrm{mM})$ and oxygen $(0.5,5$ and $20 \% \mathrm{v} / \mathrm{v})$ to a medium prepared without terminal electron acceptors and fermentable compounds.

Carbon source or terminal electron acceptors utilization were confirmed by three subsequent transfers.

\section{Metabolic end products}

Respiration and fermentation end products (2-methylbutyrate, 3-hydroxybutyrate, acetate, acrylate, formate, fumarate, gluconate, glycolate, isobutyrate, isovalerate, lactate, oxalate, propionate, succinate) were detected by chromatographic separation from cells grown for $20 \mathrm{~h}$ on Ravot medium in presence or absence of an electron acceptor (polysulphur), respectively. Cells were centrifuged and stored in an acid-rinsed glass vial at $-20^{\circ} \mathrm{C}$. Anions concentrations were determined using a Dionex ICS-2000 Reagent-Free Ion Chromatography 
System equipped with an AS50 autosampler (Dionex Camberley UK). Chromatographic separation was conducted using two Ionpac AS15 columns $(4 \times 250 \mathrm{~mm})$ in series at $30{ }^{\circ} \mathrm{C}$ and the determination of species was carried out using an Anion Self-Regenerating Suppressor (ASRS 300 4-mm) unit in combination with a DS6 heated conductivity cell (35 ${ }^{\circ} \mathrm{C}$ ). The gradient program was as followed: $8 \mathrm{mM} \mathrm{KOH}$ (29.9 min), increase $28.5 \mathrm{mM} \mathrm{KOH}$ min-1 to $65 \mathrm{mM}$ (30.1 $\mathrm{min})$, decrease $57 \mathrm{mM} \mathrm{KOH} \mathrm{min-1} \mathrm{to} 8 \mathrm{mM}$ (9 min).

\section{Results}

\section{Metabolic end products}

Metabolic end products of the fermentation of complex peptides sources were isovalerate $(124 \mu \mathrm{M})$, acetate $(54 \mu \mathrm{M})$, propionate $(21 \mu \mathrm{M})$, formate $(13 \mu \mathrm{M})$, isobutyrate $(9 \mu \mathrm{M})$ and 2methylbutyrate $(5 \mu \mathrm{M})$, when no terminal electron acceptor was provided. In the presence of polysulphur as an external terminal electron acceptor, isovalerate $(820 \mu \mathrm{M})$, acetate $(698$ $\mu \mathrm{M})$, succinate $(611 \mu \mathrm{M})$, 2-methylbutyrate $(546 \mu \mathrm{M})$, formate $(157 \mu \mathrm{M})$, isobutyrate (93 $\mu \mathrm{M})$, propionate $(92 \mu \mathrm{M})$ and fumarate $(13 \mu \mathrm{M})$ were the major catabolic end products of proteinaceous substrates. 


\section{Supplementary Figures and Tables}

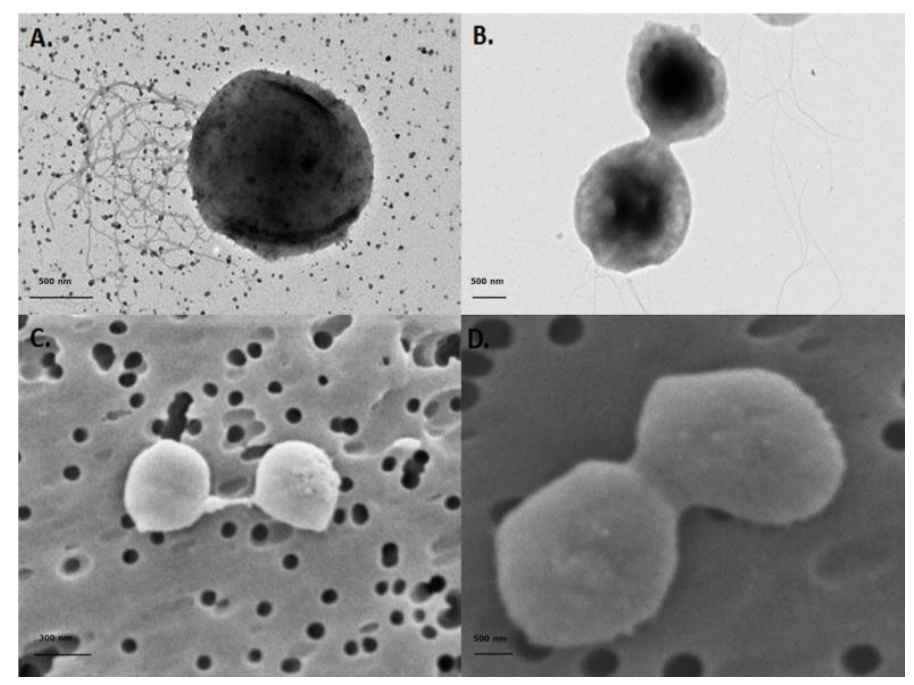

Fig. S1. Transmission (A, B) and scanning (C, D) electron micrographs of cells of strain $\mathrm{CDGS}^{\mathrm{T}}$ in exponential growth phase $\left(75^{\circ} \mathrm{C}\right)$ showing division by constriction $(\mathrm{B}, \mathrm{D})$.

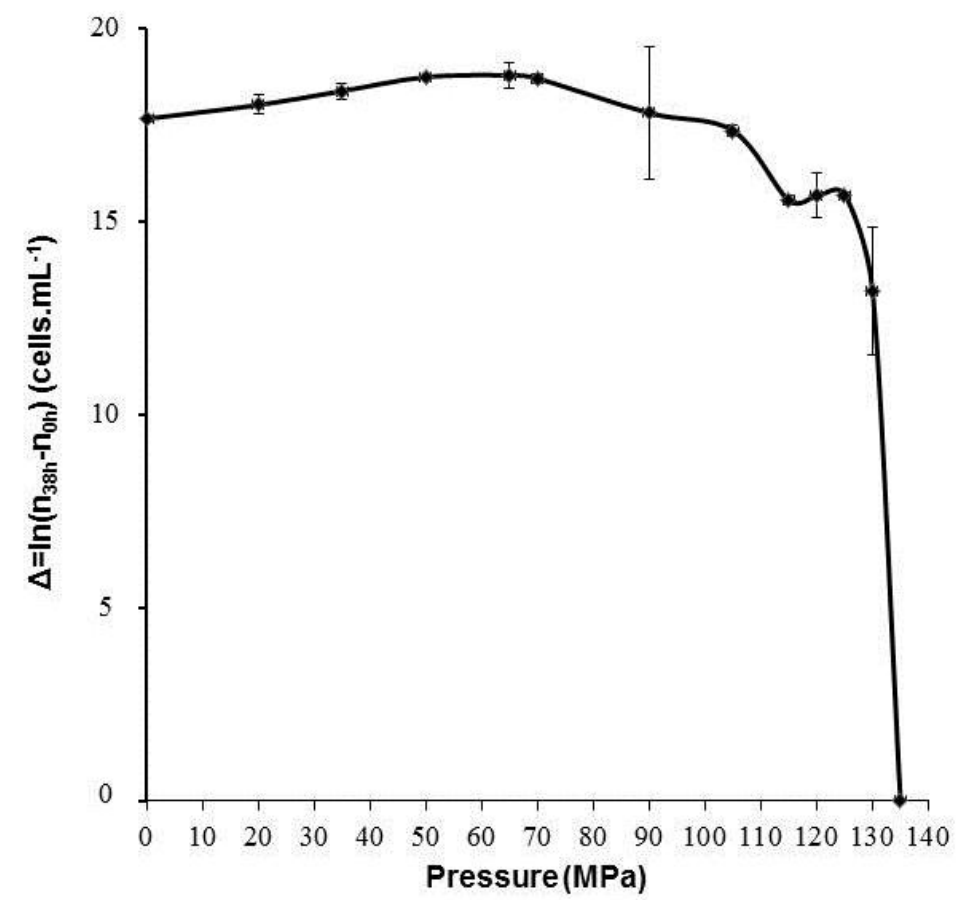

Fig. S2. Cell number evolution over $38 \mathrm{~h}$ of incubation at different pressures. 


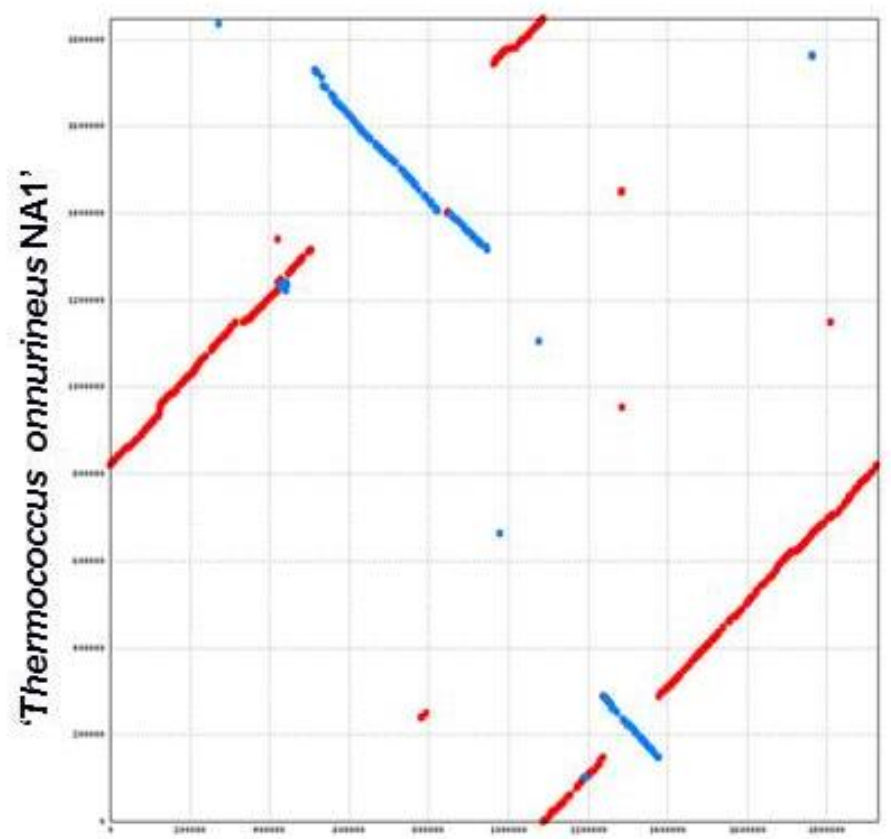

Thermococcus piezophilus CDGS ${ }^{\top}$

Fig. S3. Graphical representation (dot plot) of the regional self-similarity between the genomes of 'T. onnurineus' strain NA1 and the novel isolate $\mathrm{CDGS}^{\mathrm{T}}$.

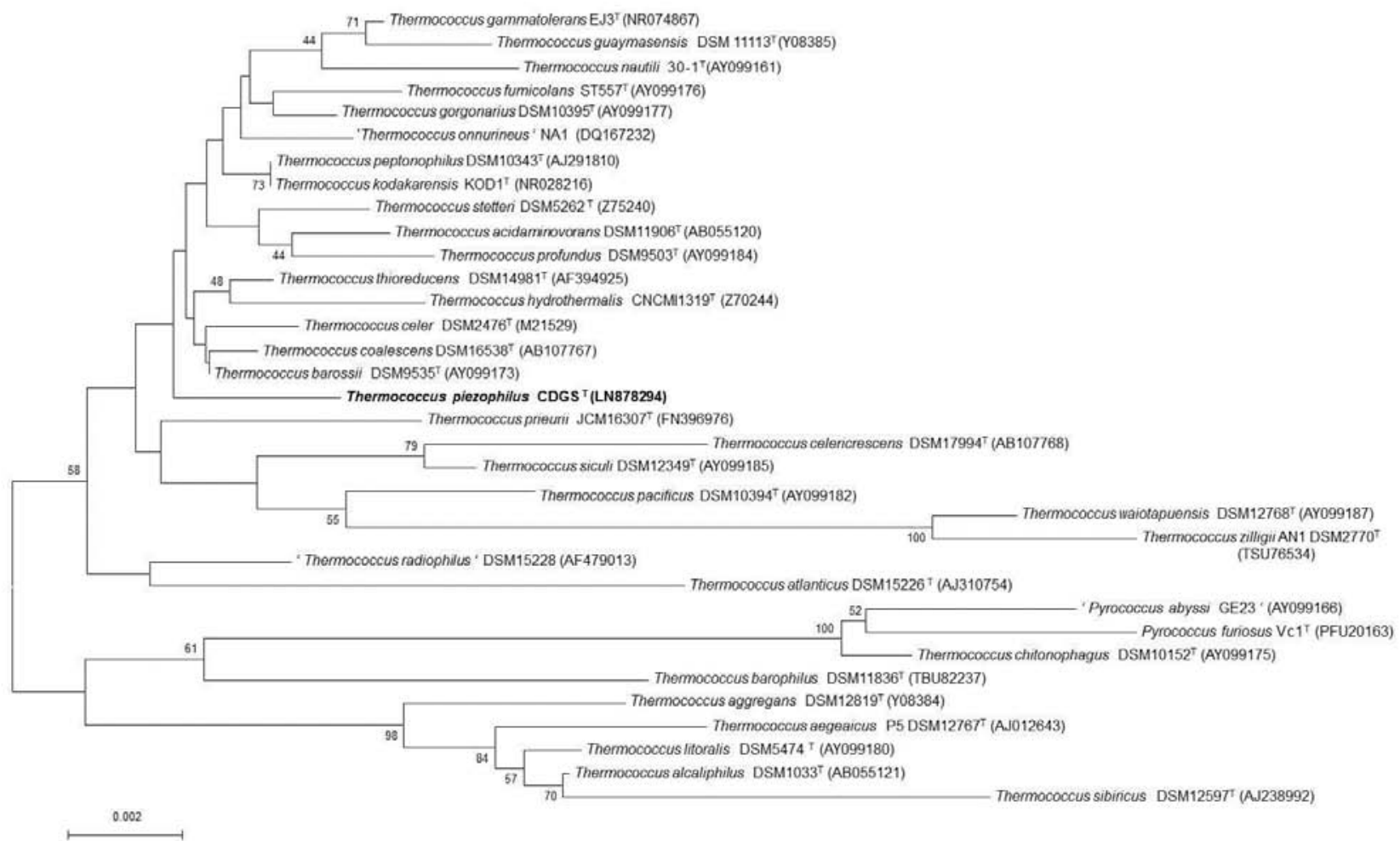

Fig. S4. Phylogenetic tree showing the relationships between strain $\mathrm{CDGS}^{\mathrm{T}}$ and other Thermococcus species based on a neighbor-joining method with Jukes and Cantor corrections 
for the analysis of 16S rRNA gene sequences $(1300 \mathrm{nt})$. The novel isolate is indicated in bold. Accession numbers are given in brackets. Bootstrap values (\%) are based on 1000 replicates. Bar, 2 substitutions per 1000 nt.

Table S1. Growth yields after 14 hours of incubation, growth rates $(\mu)$ and latency phase (Lag) duration were determined as a function of hydrostatic pressure, for pressures around the optimal pressure for growth.

\begin{tabular}{l|l|l|l|l|l|}
\hline & $\mathbf{4 0} \mathbf{M P a}$ & $\mathbf{5 0} \mathbf{~ M P a}$ & $\mathbf{5 5} \mathbf{~ M P a}$ & $\mathbf{6 0 ~ M P a}$ & $\mathbf{6 5} \mathbf{M P a}$ \\
\hline $\begin{array}{l}\text { Growth } \\
\text { yield } \\
(\text { cell.mL }\end{array}$ & $\left.7.2 \cdot 10^{-1}\right)$ & $4.9 \cdot 10^{8}$ & $2.9 \cdot 10^{8}$ & $3.0 \cdot 10^{8}$ & $3.2 \cdot 10^{8}$ \\
\cline { 2 - 6 } & \pm 0.03 & \pm 0.18 & \pm 0.11 & \pm 0.01 & \pm 0.02 \\
\hline $\boldsymbol{\mu ( \mathbf { h } ^ { - 1 } )}$ & 0.30 & 0.45 & 0.38 & 0.35 & 0.32 \\
\hline Lag (h) & 2 & 0 & 1 & 1 & 1 \\
\hline
\end{tabular}

Table S2. General features of strain $\mathrm{CDGS}^{\mathrm{T}}$ and 'Thermococcus onnurineus' NA1 genomes

\begin{tabular}{ccc} 
& Strain CDGS $^{\top}$ & ' $\boldsymbol{T}$. onnurineus' NA1 \\
\hline Isolation source & Deep-sea hydrothermal vent & Deep-sea hydrothermal vent \\
Genome size (bp) & - Cayman Trough & - East Manus Basin \\
GC \% & $1,928,919$ & $1,847,607$ \\
Number of CDS & 51.11 & 51.27 \\
Genes classified into & 2,418 & 2,029 \\
Cluster of Orthologous & 1,199 & 1,100 \\
Groups (COG) of functions & & 831 \\
Average CDS length (bp) & 709 & 90.65 \\
Protein coding density (\%) & 87.71 & 1 \\
23S rRNA & 1 & 1 \\
16S rRNA & 1 & 2 \\
5S rRNA & 2 & 46 \\
tRNA & 45 & 0 \\
Extrachromosomal & 0 & \\
elements & &
\end{tabular}


Table S3. Intracellular ATP content (i[ATP]) per cell at different pressures.

\begin{tabular}{l|lllllll}
\hline & $\mathbf{0 . 1} \mathbf{~ M P a}$ & $\mathbf{5 0 ~ M P a}$ & $\mathbf{1 2 0} \mathbf{~ M P a}$ & $\mathbf{1 2 5} \mathbf{~ M P a}$ & $\mathbf{1 3 0} \mathbf{~ M P a}$ & $\mathbf{1 3 5} \mathbf{~ M P a}$ \\
\hline $\begin{array}{l}\text { Average } \\
\text { cell number } \\
\text { (cells/ mL) }\end{array}$ & $1.210^{8} \pm$ & $1.710^{8} \pm$ & $7.010^{6} \pm$ & $1.810^{6} \pm$ & $1.410^{6} \pm$ & $2.210^{6} \pm$ \\
& $3.310^{7}$ & $1.110^{7}$ & $9.510^{5}$ & $1.510^{5}$ & $1.010^{5}$ & $2.110^{5}$ \\
\hline [iATP]/cell & $4.810^{-6} \pm$ & $2.110^{-6} \pm$ & $2.110^{-6} \pm$ & $1.310^{-5} \pm$ & $1.110^{-5} \pm$ & Close to 0 \\
(pmol) & $1.810^{-7}$ & $3.310^{-7}$ & $2.510^{-8}$ & $1.310^{-6}$ & $7.9510^{-11}$ & \\
\hline
\end{tabular}

